\title{
EFFECT OF NEOMYCIN ON PHOSPHOINOSITIDE LABELLING AND CALCIUM BINDING IN GUINEA-PIG INNER EAR TISSUES IN VIVO AND IN VITRO ${ }^{1}$
}

\author{
Angela Orsulakova, ${ }^{2}$ Eva Stockhorst and Jochen Schacht \\ Kresge Hearing Research Institute and Department of Biological Chemistry. University of Michigan. \\ Ann Arbor, MI 48104, U.S.A.
}

(Received 26 December 1974. Accepted 14 July 1975)

\begin{abstract}
Phospholipids of guinea-pig inner ear tissues were labelled in vivo by perilymphatic perfusion of the cochlea with $\left[{ }^{32} \mathrm{P}\right]$ orthophosphate or myo- $\left[{ }^{3} \mathrm{H}\right]$ inositol. After $20-40 \mathrm{~min}$ the most highly labelled ${ }^{32} \mathrm{P}$-lipids were phosphatidylinositol phosphate and diphosphate. Incorporation of $\left[{ }^{3} \mathrm{H}\right]$ inositol proceeded in the order phosphatidylinositol $>$ phosphatidylinositol phosphate $>$ phosphatidylinositol diphosphate.

After treatment of animals with neomycin for 3 weeks, ${ }^{32} \mathrm{P}$-incorporation into phosphatidylinositol diphosphate, but not into other lipids, was significantly decreased in the preparations of the organ of Corti and stria vascularis. In homogenates of inner ear tissues, the labelling of the polyphosphoinositides by $\left[\gamma_{-}{ }^{32} \mathrm{P}\right] \mathrm{ATP}$ was increased and the hydrolysis of these lipids was blocked in the presence of $10^{-4} \mathrm{M}$-neomycin. Neomycin also competitively inhibited the binding of ${ }^{45} \mathrm{Ca}^{2+}$ to homogenates of these tissues.
\end{abstract}

THEIR potent antibacterial action has made streptomycin, neomycin, and related aminoglycosidic antibiotics indispensable therapeutic agents. The bactericidal mechanism has been linked to the ability of these drugs to inhibit protein synthesis by binding to the $30 \mathrm{~S}$ ribosomal subunit of prokaryotic cells (PestKa, 1971). These aminoglycosides can also exert a number of toxic effects on mammalian tissues. These effects include convulsions after intracisternal injection (Molitor \& KUNA. 1947), blocking of neuromuscular and ganglionic transmission (PrTTINGER \& ADAMSON, 1972), nephrotoxicity, and ototoxicity in the cochlea and the vestibular system (HAwKINS, 1970). The biochemical mechanism of these actions on eukaryotic cells remains unclear.

The ototoxicity of the aminoglycosidic antibiotics is the single most important factor that restricts their clinical use. It becomes evident only after chronic administration of the antibiotics, which may be due to the slow accumulation of the drug in the inner ear (STUPP, 1970). That the underlying mechanism may be related to that of the acute actions can be inferred from studies on the lateral line organ. Here, strepto-

${ }^{1}$ A preliminary report has been published (SCHACHT, 1974a). This rescarch was supported by NIH-NIEHS con tJact No. NOl-ES-2-2110 and NIH Program Project Grant No. 05785.

${ }^{2}$ Permanent address: Forschungslabor für Akustische Medizin, Universität Düsseldorf, 4 Düsseldorf 1, Germany.

Abbreviations used: PhA, phosphatidic acid (1,2-diacylsn-glycero-3-phosphate); $\mathrm{PhC}, \mathrm{PhE}, \mathrm{PhS}$, phosphatidyl choline, ethanolamine, serine; PhI, PhIP, PhIP 2 , phosphatidylinositol, phosphate, diphosphate. mycin rapidly but reversibly suppresses the microphonic output (WERSÄLL \& FLOCK, 1964). This and the various neurotoxic effects seem to link the action of the drugs to bioelectrical events at the membrane. The stimulation or blocking of such membrane phenomena by neurotransmitters (HoKIN, 1969), convulsants (Schacht \& AGranofF, 1972), or depressants (MARGolis \& Heller, 1966), has been associated with phosphoinositide metabolism. Phosphoinositide metabolism may also be involved in the binding and release of calcium at the membrane (KAI \& HAWTHORNE, 1969; BUCKLEY \& HAWTHORNE, 1972; ReDMAN, 1972). An interference by the aminoglycosides with the calcium equilibrium at the membrane has been proposed for the neuromuscular junction (Corrado, 1963; Vital Brazil \& Prado-FranCESCHI, 1969; GoODMAN et al., 1974). We, therefore, investigated the influence of neomycin on the metabolism of phosphoinositides in the inner ear.

\section{METHODS}

Albino guinea-pigs ( $300-500 \mathrm{~g})$ were used in these experiments. The animals were anaesthetized with Nembutal $(40-50 \mathrm{mg} / \mathrm{kg}$ body wt) and maintained under artificial respiration. The otic capsule was surgically exposed and both the round and oval windows were carefully opened. "Artificial perilymph" (RAUCH \& KöstLIN, 1964) containing $1 \mathrm{~mm} \mathrm{P}_{\mathrm{i}}$ and $0.2-0.5 \mathrm{mCi}^{32} \mathrm{P}_{\mathrm{i}} / \mathrm{ml}$ or $1 \mathrm{mCi}\left[{ }^{3} \mathrm{H}\right] \mathrm{myo}-$ inositol $/ \mathrm{ml}$ was perfused through the perilymphatic spaces once at the start of the experiment and then remained in the cochlea. At the end of the incubation time the cochlea was perfused with $10 \%$ neutral formaldehyde (see Results) and the tissues were dissected. 
Microdisscction of inner ear tissues was performed in $10 \%$ neutral formaldehyde under the light microscope. The cochlear bone was cut longitudinally and was removed with spiral ligament and stria vascularis attached. Stria vascularis was lifted from the spiral ligament by pushing a glass rod between the two tissues. This glass rod was prepared by fusing the tip of a microcapillary over a flame and abrading the tip with sandpaper. Spiral ligament was then removed from the bone. The entire organ of Corti including the supporting cells and the osseous spiral lamina was mounted on a glass slide in $12 \%$ gelatine. Under high magnification the osseous spiral lamina was dissected with a sharpened piece of a razor blade.

Tissues were collected in chloroform-methanol $(1: 2, \mathrm{v} / \mathrm{v})$ and a guinea-pig brain homogenate (1 $\mathrm{mg}$ protein) was added as a source of carrier lipids. Lipids were extracted with $2.5 \mathrm{ml}$ chloroform-methanol-concentrated $\mathrm{HCl}$ (3:2:0.05, by vol) $/ 1.0 \mathrm{ml} 1 \mathrm{M}-\mathrm{KCl}$ (HaJRA et al., 1968). Aliquots of the resulting upper phase were analyzed for ' $\mathrm{HCl}$ soluble ${ }^{32} \mathrm{P}$ '. The lower layer was washed with $2 \mathrm{ml}$ chloroform-methanol- $0.04 \mathrm{~N}-\mathrm{HCl}(3: 48: 47$, by vol). Lipids were separated on silica gel plates (Brinkman Silplate 22) in chloroform-methanol-conc aqueous $\mathrm{NH}_{3}-\mathrm{H}_{2} \mathrm{O}$ (45:45:3.5:11, by vol). This system gave good and reproducible separations of phosphatidylinositol phosphate and diphosphate from the other lipids but separation of phosphatidylinositol from phosphatidylserine was poor. Lipids were identified by co-chromatography with known standards (Supelco, Bellefonte. PA) in ammoniacal and acetic (SKIPSKI et al., 1964) solvents, or by high voltage electrophoresis of the water soluble products after alkaline methanolysis (Hajra et al., 1968). Phosphatidylinositol phosphate and diphosphate were a gift of Dr. B. W. Agranoff, University of Michigan. ${ }^{32} \mathrm{P}$-lipids on TLC plates were located by radioautography. scraped, and counted by liquid scintillation. ${ }^{3} \mathrm{H}$-lipids were located from the radioautographically established $R_{f}$ values of ${ }^{32} \mathrm{P}$-lipids chromatographed on the same plates.

Tissues from more than 50 cochleae were pooled and homogenized in 0-32 M-sucrose for in vitro experiments. The homogenates were centrifuged for $10 \mathrm{~min}$ at $1000 \mathrm{~g}$ to remove cellular debris and nuclei. Aliquots of the supernatant fraction were employed in the study of lipid labelling by $\left[\gamma^{32} \mathrm{P}\right] \mathrm{ATP}$, hydrolysis of ${ }^{32} \mathrm{P}$-lipids, and binding of ${ }^{45} \mathrm{CaCl}_{2}$.

For lipid labelling, incubations were performed at $37^{\circ} \mathrm{C}$ in air with shaking under the following conditions: a brain lipid extract ("Peak E" of a DEAE cellulose fractionation, Hendrickson \& Ballou, 1964) as a source of substrate for polyphosphoinositide labelling was suspended in 0.2 M-Tris $-\mathrm{HCl} \mathrm{pH} 7.4$ with a Polytron PT 10-35 (Brinkman Instr.). An aliquot of this suspension $(1 \mu \mathrm{mol}$ lipid-P per assay tube) was incubated with the tissue homogenates for $15 \mathrm{~min}$ in the presence or absence of neomycin in 40 mM-Tris- $\mathrm{HCl} \mathrm{pH} \mathrm{7.4,10} \mathrm{mm-dithioerythritol;} \mathrm{vol} 0.25 \mathrm{ml}$. Then were added (final concn) $80 \mathrm{~mm}$-Tris- $\mathrm{HCl} \mathrm{pH} 7.4$. $20 \mathrm{~mm}-\mathrm{MgCl}_{2}, 0 \cdot 2 \mathrm{~mm}-\mathrm{EDTA}$, and $4 \mathrm{mM}-\left[\gamma_{-}{ }^{32}\right.$ P $]$ ATP; final vol, $0.5 \mathrm{ml}$. Thirty min thereafter the incubations were terminated by the addition of $2 \mathrm{ml}$ chloroform-methanol. $\mathrm{HCl}(1: 2: 0.03$; by vol) and lipids were processed as above.

Hydrolysis of phospholipids was studied with ${ }^{32} \mathrm{P}$-labelled lipids extracted from guinea-pig kidney after intraperitoneal injection of ${ }^{32} \mathbf{P}_{i}$ or from in vitro incubations of guinea-pig cerebral cortex synaptosomes (SCHACHT \& AgRANOFF, 1974b). The lipid extract was taken to dryness under $\mathrm{N}_{2}$ and suspended in Tris- $\mathrm{HCl}$ pH 7.4 with a Poly- tron PT 10-35 (Brinkman Instr.). Aliquots of this suspension were incubated at $37^{\circ} \mathrm{C}$ with the fractions in (final concn) $100 \mathrm{~mm}$-Tris- $\mathrm{HCl} \mathrm{pH} 7 \cdot 4,1 \mathrm{mM}-\mathrm{MgCl}_{2}$ and $1 \mathrm{~mm}$ $\mathrm{NaF}$ for $20 \mathrm{~min}$; vol. $0-3 \mathrm{ml}$. The incubations were terminated and lipids extracted as above.

Calcium binding was measured by incubating the tissue fractions for $10 \mathrm{~min}$ in $80 \mathrm{~mm}$-sodium-HEPES buffer $\mathrm{pH}$ 7.4 with $1 \mu \mathrm{Ci}{ }^{45} \mathrm{CaCl}_{2}$; vol, $0.25 \mathrm{ml}$. Bound calcium was assayed by centrifugal sedimentation. The pellet $(14,000 \mathrm{~g}$ for $20 \mathrm{~min}$ ) was dissolved in $0.5 \mathrm{ml} 1 \mathrm{~N}-\mathrm{NaOH} / 1 \mathrm{~mm}-\mathrm{ED}-$ $\mathrm{TA}$, an aliquot was neutralized with acetic acid and counted by liquid scintillation spectrometry. $\left[\gamma_{-}{ }^{32} \mathrm{P}\right]$ ATP was prepared enzymatically (GLYNN \& CHAPPEL, 1964) and protein determined spectrophotometrically (LownY et al., 1951). Neomycin B was a gift from The Upjohn Company (Kalamazoo, Mich.). Radioactive materials were purchased from New England Nuclear (Boston, Mass.).

\section{RESULTS}

\section{Labelling of inner ear lipids}

Of three possible routes of isotope application to the inner ear - intraperitoneal or intracisternal injection, or perilymphatic perfusion - only the last yielded lipids labelled enough to permit analysis of tissues from a single cochlea (SCHACHT, 1974h). In view of the high rate of post-mortem hydrolysis of the polyphosphoinositides (HAustr et al., 1971) various methods were investigated for the quick fixation of inner ear tissues taking the ratio of $\mathrm{PhIP}_{2}: \mathrm{PhI}$ as a sensitive measure of $\mathrm{PhIP}_{2}$ breakdown (Table 1).

Freezing the cochlea in situ with Freon, followed by immersion of the dissected temporal bone into liquid nitrogen and by freeze drying, is an established way to minimize post-mortem events in the inner ear (Thalmann et al., 1972). Fixation with formaldehyde or glutaraldehyde by cochlear perfusion appears equally effective for the preservation of labelled cochlear lipids. Since dissection of tissues is best accomplished after formaldehyde fixation this was the method of choice. Microwave irradiation (1200 W, $30 \mathrm{~s})$ proved unsuitable, longer exposure led to tissue coagulation. It may seem surprising that microwave irradiation which is a rapid way of tissue fixation to prevent post-mortem breakdown of substrates (STAVINOHA et al., 1970), is not effective in the case of the

TABle 1. COMPARISON OF FIXATION METhODS

\begin{tabular}{|c|c|c|}
\hline Fixation & Dissection & $\frac{\text { d.p.m. PhIP, }}{\text { d.p.m. PhI }+ \text { PhS }}$ \\
\hline $\begin{array}{l}\text { Freon in situ } \\
\quad+\text { lrecese drying }\end{array}$ & room temperature & 1.6 \\
\hline $10 \%$ Formaldehyde & cold formaldehyde & $1 \cdot 6$ \\
\hline $10 \%$ Glutaraldehyde & cold glutaraldehyde & 1.6 \\
\hline Microwave irradiation & $0-4^{\circ} \mathrm{C}$ & 0.4 \\
\hline $\begin{array}{l}\text { Microwave } \\
\text { irradiation }\end{array}$ & room timperature & 0.1 \\
\hline
\end{tabular}

Guinea-pigs received a perilymphatic perfusion as described in Methods. Incubation time $60 \mathrm{~min}$ with $250 \mu \mathrm{Ci}$ ${ }^{32} \mathbf{P}_{i} / \mathrm{ml}$. A preparation of spiral ligament and stria vascularis was analyzed. Numbers are average values obtained from 2 animals. 


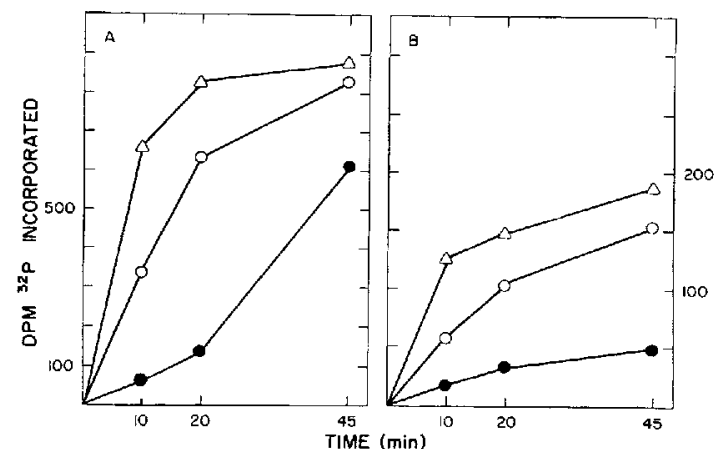

FIG. 1. Time-course of labelling of cochlear phosphoinositides by ${ }^{32} \mathbf{P}_{i}$. Guinea-pigs received a perilymphatic perfusion as described in Methods with $250 \mu \mathrm{Ci}{ }^{32} \mathbf{P}_{i} / \mathrm{ml}$. Numbers are mean values from 3 animals. A: Stria vascularis + spiral ligament; B: organ of Corti + osseous spiral lamina. $\triangle-\triangle \mathrm{PhIP}_{2} ; \mathrm{O} \quad \mathrm{OPhIP} ; \bullet \mathrm{PhI}$.

polyphosphoinositides. However, $\mathrm{PhIP}_{2}$ phosphodiesterase from ox brain has been reported to be relatively heat stable (Krovgh \& ThOMpson, 1972), and the loss of $\mathrm{PhIP}_{2}$ may be due to enzymatic activity rather than due to secondary effects of irradation. This is supported by the fact that ${ }^{32} \mathrm{P}-\mathrm{PhIP}_{2}$ is lower when the tissue is handled at room temperature rather than at $0^{\circ} \mathrm{C}$.

With these methods, rapid labelling of phosphoinositides in the inner ear can be demonstrated (Fig. 1). $\mathrm{PhIP}_{2}$ and $\mathrm{PhIP}$ show the highest initial rate of ${ }^{32} \mathrm{P}$-incorporation, followed by PhI. Labelling of other lipids proceeds more slowly (Table 2 ). The onedimensional TLC routinely used in these experiments does not separate $\mathrm{PhI}$ and $\mathrm{PhS}$. However, additional analyses by two-dimensional TLC (PUMPHREY, 1969) showed that there is only minimal ${ }^{32} \mathrm{P}$-incorporation into $\mathrm{PhS}$ at short times. The labelling pattern of the phosphoinositides is reversed with $\left[{ }^{3} \mathrm{H}\right]$ inositol as the precursor (Table 3). Radioactivity in $\mathrm{PhI}$ exceeds that in PhIP. Incorporation into $\mathrm{PhIP}_{2}$ could only be demonstrated in spiral ligament.

\section{Effect of neomycin treatment}

Guinca-pigs received subcutaneous injections of neomycin ( $100 \mathrm{mg} / \mathrm{kg}$ body wt) daily for 2 or 3 weeks,

TABle 2. Labeling of COChLEAR Lipids AFter $180 \mathrm{MIN}$

\begin{tabular}{|c|c|c|}
\hline Lipid & $\begin{array}{c}\text { Stria } \\
\text { vascularis }+ \text { spiral } \\
\text { ligament }\end{array}$ & $\begin{array}{c}\text { Organ of } \\
\text { corti + osseous } \\
\text { spiral lamina }\end{array}$ \\
\hline & \multicolumn{2}{|c|}{ d.p.m. ${ }^{32} \mathbf{P}$ incorporated } \\
\hline Phosphatidylinositol diphosphate & 6660 & 2890 \\
\hline Phosphatidylinositol phosphate & 4440 & 2710 \\
\hline Phosphatidylinositol + -serinc & 3450 & 2640 \\
\hline Phosphatidyl choline & 573 & 220 \\
\hline Phosphatidyl ethanolamine & 282 & 172 \\
\hline (Lyso-phosphatidyl choline)* & 742 & 220 \\
\hline Unknown & 254 & 129 \\
\hline
\end{tabular}

Guinea-pigs received a perilymphatic perfusion as described in Methods. Perfusion medium $\left(250 \mu \mathrm{Ci}{ }^{32} \mathrm{P}_{i} / \mathrm{ml}\right)$ was exchanged every $45 \mathrm{~min}$; total incubation time, 180 min. Numbers are averages from 3 animals.

* Identified by co-chromatography with known standard in one solvent only (see Methods).
TABLE 3. LABELLING OF COCHLEAR PHOSPHOINOSITIDES BY ${ }^{3}$ H-INOSITOL

\begin{tabular}{lrcc}
\hline & PhI & PhIP & PhIP $_{1}$ \\
\cline { 2 - 4 } \multicolumn{1}{c}{ Tissue } & \multicolumn{3}{c}{ d.p.m. ${ }^{3}{ }^{3}$ incorporated } \\
\hline Spiral ligament & 9235 & 330 & 109 \\
Striaa vascularis & 1536 & 82 & $*$ \\
Organ of Corti & 891 & 51 & $*$ \\
\hline
\end{tabular}

Guinea-pigs received a perilymphatic perfusion as described in Methods with $1 \mathrm{mCi}\left[{ }^{3} \mathrm{H}\right]$-myo-inositol/ml. Incubation time $2 \mathrm{~h}$. Numbers are mean values obtained from 4 animals.

* Not sufficiently high above background.

and the labelling of their inner ear lipids was compared to that of untreated animals (Table 4). There were 12 animals per experimental condition, and ${ }^{32} \mathrm{P}$. lipids were analyzed after combining tissues from 2 or 3 animals. The ${ }^{32} \mathrm{P}$-content of lipids was normalized to the ${ }^{32} \mathrm{P}$-content in the $\mathrm{HCl}$ soluble fraction of the tissue samples to correct for variabilities in dissection and perfusion. Data were subjected to analysis of variance for every possible contrast between pairs. There were no significant changes with drug treatment in the labelling of $\mathrm{PhI} .{ }^{32} \mathrm{P}$-incorporation into PhIP appeared somewhat more variable, and an increase was seen after 3 weeks of neomycin treatment in the organ of Corti $(P=0.02)$. $\mathrm{PhIP}_{2}$ labelling showed a consistent trend in response to drug treatment. There was virtually no change in any of the tissues after 2 weeks, but a decrease of labelling was evident after 3 weeks of neomycin injections in the organ of Corti $(P=0.02)$, spiral ligament $(P=0.05)$ and stria vascularis $(P=0.05)$.

To assess further the significance of the decreases in $\mathrm{PhIP}_{2}$ labelling, these results were compared to those obtained in a preliminary experiment. In this case, the drug treatment had been the same, but the perfusion time with ${ }^{32} \mathbf{P}_{i}$ was $30 \mathrm{~min}$. Tissues from four cochleae had been pooled for analysis. Again, we found a decrease in $\mathrm{PhIP}_{2}$ labelling in the organ

TABLE 4. EFFECT OF NEOMYCIN TREATMENT ON LABELLING OF PHOSPHOINOSITIDES in vivo

\begin{tabular}{|c|c|c|c|}
\hline & \multirow[b]{2}{*}{ Contral } & \multicolumn{2}{|c|}{ Drug treatmont } \\
\hline & & 2 weeks & 3 weeks \\
\hline Spiral ligament & \multicolumn{3}{|c|}{$10^{3} \times$ d.p.m. lipid- ${ }^{32} \mathrm{p} / \mathrm{HCl}$-sol. ${ }^{32} \mathrm{P}$} \\
\hline $\mathrm{PhI}+\mathrm{PhS}$ & $9 \cdot 3 \pm 1 \cdot 9$ & $11 \cdot 2 \pm 2 \cdot 2$ & $13 \cdot 4+2 \cdot 4$ \\
\hline PhIP & $13 \cdot 6+4.7$ & $23.5 \pm 4.9$ & $12 \cdot 2 \pm 2 \cdot 3$ \\
\hline $\begin{array}{l}\mathrm{PhIP}_{2} \\
\text { Stria vascularis }\end{array}$ & $9 \cdot 5 \pm 4.6$ & $14 \cdot 1 \pm 3 \cdot 9$ & $5 \cdot 4 \pm 1 \cdot 1^{*}$ \\
\hline $\mathrm{PhI}+\mathrm{PhS}$ & $46 \cdot 4 \pm 15 \cdot 0$ & $47 \cdot 3 \pm 19.7$ & $40 \cdot 4 \pm 13 \cdot 7$ \\
\hline $\mathrm{PhIP}$ & $543+243$ & $64.1 \pm 22 \cdot 8$ & $35.7 \pm 6.1$ \\
\hline $\begin{array}{l}\text { PhIP }_{2} \\
\text { Organ of Corti }\end{array}$ & $24 \cdot 3 \pm 7 \cdot 8$ & $28.9 \pm 10.1$ & $13.2 \pm 3.9^{*}$ \\
\hline $\mathrm{PhI}+\mathrm{PhS}$ & $12 \cdot 3 \pm 19$ & $11 \cdot 2 \pm 3 \cdot 7$ & $19 \cdot 0 \pm 2 \cdot 7$ \\
\hline PhIP & $12.0 \pm 2.7$ & $13 \cdot 4 \pm 3 \cdot 3$ & $19.4 \pm 24 \dagger$ \\
\hline $\mathrm{PhIP}_{2}$ & $59 \pm 1 \cdot 1$ & $5.7 \pm 1.7$ & $2.7 \pm 0.8 \dagger$ \\
\hline
\end{tabular}

Guinea-pigs received a perilymphatic perfusion as described in Methods, with $250 \mu \mathrm{Ci}^{32} \mathrm{P}_{\mathrm{i}} / \mathrm{ml}$. Incubation time $60 \mathrm{~min}$. Drug treatment was $100 \mathrm{mg} / \mathrm{kg}$ body wt daily. Spiral ligament and stria vascularis: for each of the conditions, four samples were analyzed (tissues from 12 guineapigs in pools of 3): spiral ligament, 6 samples (pools of 2 tissues). Numbers are mcans + S.D.

$* P=0.05 ; \dot{\dagger} P=0.02$ (One-way ANOVA). 
TABLE 5. EFFECT OF NEOMYCIN ON LABELLING OF POLYPHOSPHOINOSITIDES in vitro

\begin{tabular}{lcc}
\hline & PhIP & PhIP $_{2}$ \\
\hline & \multicolumn{1}{c}{ d.p.m. ${ }^{32} \mathrm{P}$ incorporated } \\
Control & 6634.7406 & 733,878 \\
$10^{-4} \mathrm{M}$ neomycin & 8406,8766 & 1023,1253
\end{tabular}

A homogenate of stria vascularis and spiral ligament (0.24 mg protein) was incubated with $60 \mu \mathrm{Ci}\left[{ }^{32} \mathrm{P}\right] \mathrm{ATP}$ for $30 \mathrm{~min}$ as described in Methods. Numbers are values of duplicate incubations.

of Corti (control $4 \cdot 0$, treated animals 2.5 d.p.m. $/ 10^{3}$ d.p.m. $\mathrm{HCl}$ soluble $\left.{ }^{32} \mathrm{P}\right)$ and stria vascularis $(13.6 \mathrm{vs}$ $7.6)$, but this time not in spiral ligament (6.9 vs 7.5). The osseous spiral lamina which had also been analyzed in both experiments did not show any significant changes of lipid labelling.

\section{In vitro experiments}

Labelling of polyphosphoinositides by $\left[\gamma{ }^{32} \mathrm{P}\right] \mathrm{ATP}$ was demonstrated in a homogenate of stria vascularis and spiral ligament (Table 5). As with subcellular fractions from brain (SCHACHT \& AGRANOFF, 1974a), $\mathrm{PhIP}_{2}$ and PhIP are highly labelled. The presence of $10^{-4} \mathrm{M}$-neomycin appears to increase the labelling of both PhIP and $\mathrm{PhIP}_{2}$.

Hydrolysis of lipids was studied with lipids previously labelled by ${ }^{32} \mathrm{P}_{i}$ in guinea-pig brain synaptosomes (Table 6, expt. I) or kidney (Table 6, expt. II). There is no apparent hydrolysis of lipids other than $\mathrm{PhIP}$ or PhIP ${ }_{2}$. The enzymatic breakdown of the polyphosphoinositides by inner ear tissues is inhibited

TABLE 6. EFFECT OF $5 \times 10^{-4} \mathrm{M}$ NEOMYCIN ON HYDROLYSIS OF PHOSPHOLIPIDS BY INNER EAR TISSUES in vitro

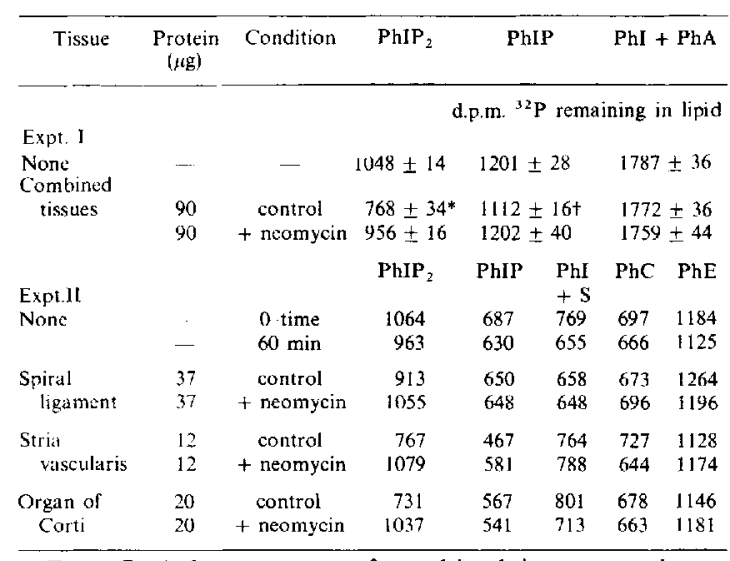

Expt. I: A homogenate of combined inner ear tissues was incubated for $60 \mathrm{~min}$ with previously labelled and extracted lipids (from guinea-pig synaptosomes, SCHACHT \& AGRANOFF, 1974b) as described in Methods. Numbers are means \pm S.D. of 3 incubations.

* Differs from incubations without enzyme, $P<0.01$ differs from incubations with neomycin, $P<0.01$.

+ Differs from incubations without enzyme, $0.02>P>0.01$; differs from incubations with neomycin $0.05>P>0.02$.

Expt. II: A $1000 \mathrm{~g}$ supernatant fraction of tissue homogenates was incubated for $60 \mathrm{~min}$ with previously labelled and extracted lipids (from guinea-pig kidney) as described in Methods. Numbers are averages of duplicate incubations.

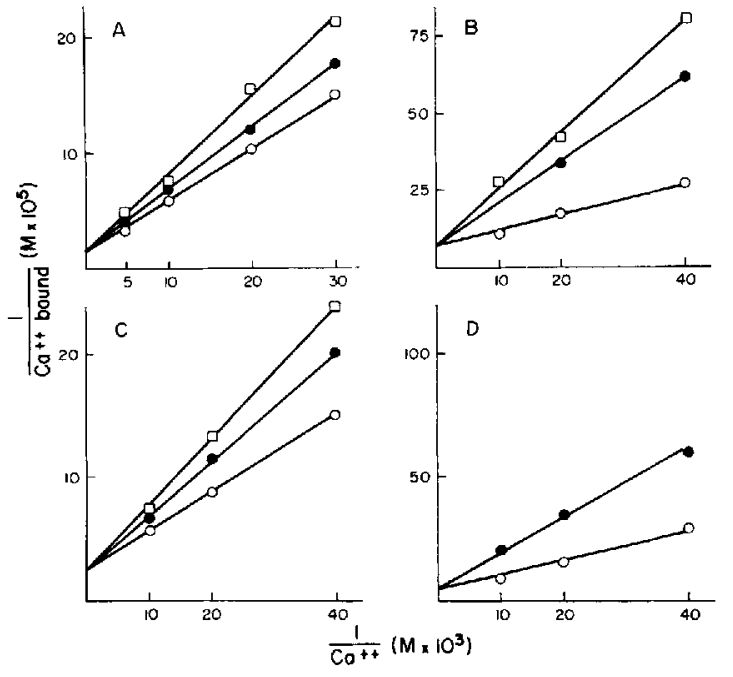

FIG. 2. Inhibition by neomycin of calcium binding. A $1000 \mathrm{~g}$ supernatant fraction of tissue homogenates was incubated with ${ }^{45} \mathrm{CaCl}_{2}(1 \mu \mathrm{Ci})$ as described in Methods. A: Combined tissues, $18 \mu \mathrm{g}$ protein; B: Spiral ligament, $35 \mu \mathrm{g}$ protein; C: Organ of Corti, $13 \mu \mathrm{g}$ protein; D: Stria vascularis, $28 \mu \mathrm{g}$ protein. $0-0$ no neomycin; $5 \times 10^{-5} \mathrm{M} ; \square-\square 5 \times 10^{-4} \mathrm{M}$ neomycin.

significantly by the addition of $5 \times 10^{-4} \mathrm{M}$-neomycin (expt. I). This effect can also be demonstrated in individual tissues with the possible exception of spiral ligament where only little if any hydrolytic activity is seen (expt. II).

In view of the possible involvement of the polyphosphoinositides in the binding of calcium, the effect of neomycin on this binding was investigated with ${ }^{45} \mathrm{CaCl}_{2}$ (Fig. 2). Neomycin acts as a competitive inhibitor of calcium binding to inner ear tissues. For one of the preparations (Fig. 2A) the binding capacity was extrapolated (SCATCHARD, 1949) and compared to the phospholipid content. There were $280 \mathrm{nmol}$ lipid- $P$ / mg protein which could bind $80 \mathrm{nmol}$ calcium. The polyphosphoinositides should not constitute more than $1-3 \%$ of the total phospholipids (SHELTAWY \& Dawson, 1969) and thus can only account for a small fraction of the calcium binding sites.

\section{DISCUSSION}

A participation of the polyphosphoinositides in the regulation of membrane permeability, possibly via their capacity to bind calcium, has been inferred from various observations. Their concentration is highest in nervous and secretory tissue (DAwSON, 1969), the labelling of their monoesterified phosphate groups is rapid (Santiago-Calvo et al., 1964), and this labelling increases with appropriate stimulation of the tissues (SCHACHT \& AGRANOFF, 1972; White et al., 1974). Such a rapid labelling can also be observed in inner ear tissues after introduction of the precursor into the perilymphatic spaces. After short incubation times, $\mathrm{PhIP}_{2}$ and PhIP are by far the most highly labelled lipids with ${ }^{32} \mathbf{P}-\mathbf{P h I P}_{2}$ exceeding PhIP. This 
labelling pattern resembles closely that observed in brain (SHELTAwY \& DAwsON, 1969), and kidney (Tou et al., 1972). After complete dissection of the car tissues, the highest rate of ${ }^{32} \mathrm{P}$-incorporation is seen in stria vascularis. This agrees well with the generally high metabolic activity ascribed to this tissue (THALMANN et al., 1970). The low labelling of $\mathrm{PhI}$ at short times suggests that the ${ }^{32} \mathrm{P}$-incorporation into $\mathrm{PhIP}$ and $\mathrm{PhIP}_{2}$ takes place largely into their monoester phosphates via kinase reactions. This is supported by the fact that the incorporation of $\left[{ }^{3} \mathrm{H}\right]$ inositol which is more a measure of de novo synthesis, proceeds in the order $\mathrm{PhI}>\mathrm{PhIP}>\mathrm{PhIP}_{2}$

Treatment of animals with neomycin for several weeks produces damage to the auditory system which can be assessed morphologically and electrophysiologically. Such analyses, carried out in parallel with the biochemical experiments indicated that injury to the inner ear by neomycin at this dose level, as judged by decrease in cochlear potentials and histological changes in the organ of Corti, begins to appear in some animals after 2 weeks of treatment and is clearly evident in all of them after 3 weeks (J. E. Hawkins, Jr.. personal communication). No apparent changes in phosphoinositide labelling are evident after two weeks of drug treatment. After 3 weeks, however, a decrease of the labelling of $\mathrm{PhIP}_{2}$ can be observed which is significant for the organ of Corti and marginally significant for the other tissues. The labelling of PhIP is somewhat more variable in the drug treated animals and a clear effect on this lipid can only be observed in the organ of Corti. Incorporation of ${ }^{32} \mathrm{P}_{i}$ into $\mathrm{PhI}$ remains unaffected. The depression of ${ }^{32} \mathrm{P}-\mathrm{PhIP}{ }_{2}$ after neomycin treatment was also seen in the second experiment in the organ of Corti and stria vascularis but not in spiral ligament. $A$ third experiment (SCHACHT, 1974b) had also shown a significant decrease in the labelling of $\mathrm{PhIP}_{2}$ in a preparation of the organ of Corti. Stria vascularis had not been dissected separately, and the combined tissues of stria vascularis and spiral ligament did not show changes in ${ }^{32} \mathrm{P}$-lipids after neomycin treatment.

Two points seem to be of interest in this context. Firstly, on the basis of morphological evidence, the organ of Corti and stria vascularis are usually considered the primary targets of ototoxic drugs (HAwKINS, 1970). Second, neomycin is also nephrotoxic and kidney tissues and siria vascularis show marked similarities in a variety of modalites (Quick et al., 1973). In kidney, we were able to demonstrate a decreased labelling of ${ }^{32} \mathrm{P}$-polyphosphoinositides after neomycin treatment in vivo as well as an inhibition of polyphosphoinositide hydrolysis in vitro (SCHACHT, in preparation). Thus neomycin seems to alter phosphoinositide metabolism in both these susceptible tissues.

In vitro experiments were conducted to answer two questions. (1) Is the change in $\mathrm{PhIP}$ labelling a direct action of neomycin or is it a secondary response, and (2) what is the underlying mechanism?
The concentrations of neomycin chosen for the in vitro experiments appear to fall well within the physiological range. Aminoglycoside antibiotics are known to accumulate in the inner ear fluids exceeding the serum concentration by an order of magnitude or more. Twelve hours after a single injection of 100 $\mathrm{mg}$ neomycin $/ \mathrm{kg}$ body wt the drug concentration in guinea-pig perilymph is about $10^{-4} \mathrm{M}$ and repeated injections would increase this level (Srupp, 1970). Labelling of PhIP and $\mathrm{PhIP}_{2}$ by $\left[\gamma^{32} \mathrm{P}\right]$ ATP appears to be stimulated in inner ear tissues in the presence of neomycin and the hydrolysis of these lipids is inhibited by the addition of $5 \times 10^{-4} \mathrm{M}$ neomycin. This inhibition may explain the higher labelling of these lipids from $\left[{ }^{32} \mathrm{P}\right] \mathrm{ATP}$ in the presence of the drug. Table 6 also shows that stria vascularis and organ of Corti have a much higher activity of polyphosphoinositide phosphomonoesterases and/or -diesterases than the spiral ligament. It is tempting to speculate that the high rate of polyphosphoinositide metabolism makes these two tissues susceptible to neomycin in vivo. However, drug penetration and accumulation may also play an important role in determining the in vivo effects.

To explain the decreased $\mathrm{PhIP}_{2}$ labelling in vivo by an inhibition of hydrolysis, we may consider, as pointed out above, that the ${ }^{32} \mathrm{P}$-incorporation in vivo probably occurs via phosphatase and kinase reactions:

$$
\begin{aligned}
\mathrm{PhIP}_{2}+\mathrm{H}_{2} \mathrm{O} & \rightarrow \mathrm{PhIP}+\mathrm{P}_{i} \\
\mathrm{PhIP}+\left[{ }^{32} \mathrm{P}\right] \mathrm{ATP} & \rightarrow\left[{ }^{32} \mathrm{P}\right] \mathrm{PhIP}_{2}+\text { ADP. }
\end{aligned}
$$

An inhibition of $\mathrm{PhIP}_{2}$ phosphomonoesterase can thus lead to a decreased rate of labelling from $\left[{ }^{32}\right.$ P]ATP if the hydrolysis is the rate-limiting step in the reaction sequence. In the in vitro labelling experiment, a phosphoinositide fraction was added to the tissue homogenate so that PhIP (and PhI) availability should no longer be rate limiting for the kinase reactions. Inhibition of hydrolysis would then increase labelled polyphosphoinositides.

A different mechanism of action could be suggested, however, by the calcium binding studies. It is evident that neomycin is a competitive inhibitor of calcium binding to inner ear tissues. An interference of neomycin with calcium at the neuromuscular junction has been discussed (Corrado, 1968; VITAL Brazil \& Prado-Franceschi, 1969), and recently an inhibition of calcium reuptake or rebinding by neomycin has been demonstrated in vascular smooth muscle (GoODMAN et al., 1974). Although the amount of calcium bound by inner ear tissues is greater than can be accounted for by the presence of polyphosphoinositides, the displacement of calcium implies that neomycin can occupy anionic binding sites. Complexes between basic antibiotics and polyanionic compounds are well documented in vitro (COHEN, 1947; Mora et al., 1959). Such a complex formation between the acidic polyphosphoinositides and the 
polybasic neomycin might render the lipids unavailable as substrates to their degradative enzymes, explaining the observed effects as described above. Moreover, such binding may, in addition, block the PhIP kinase reaction, leading to the decrease in $\mathrm{PhIP}_{2}$ and an accumulation of PhIP as observed in vivo in the organ of Corti. A dual mechanism of neomycin action, that is inhibition of $\mathrm{PhIP}_{2}$ phosphomonoesterase and the displacement of calcium from other binding sites, cannot, however, be ruled out from the present studies.

Acknowledgements - The authors are very grateful to Dr. J. E. HAWKINS, JR. for his comments and suggestions during the course of this work. Thanks are due also to the Statistical Research Laboratory, University of Michigan, for help in the statistical analysis of the data.

\section{REFERENCES}

Buckley J. T. \& Hawthorne J. N. (1972) J. biol. Chem. 247, 7218-7223.

COHEN S. S. (1947) J, biol. Chem. 168, $511-526$.

Corrado A. P. (1963) Anesth. Analg. 42, 1-5.

Dawson R. M. C. (1969) Ann. N.Y. Acad. Sci. 165, $774-783$

Glynn I. M. \& Chappel J. B. (1964) Biochem. J. 90, 147-154.

Goodman F. R., Weiss G. B. \& Adams H. R. (1974) J. Pharmac. exp. Ther. 188, 472-480.

Hajra A. K., Seguin E. B. \& Agranoff B. W. (1968) $J$. biol. Chem. 243, 1609-1616.

Hauser G., Eichberg J. \& Gonzales-Sastre F. (1971) Biochim. biophys. Acta. 248. 87-95.

HaWkins J. E. JR. (1970) in Biochemical Mechanisms in Hearing and Deafness (PAPARella M. M., ed.) pp. 323-339. Thomas, Springfield.

Hendrickson H. S. \& Ballou C. E. (1964) J. biol. Chem. 239, 1369-1373.

HokIN L. E. (1969) in Structure and Function of Nervous Tissue (Boukne. G. E.. ed.) Vol. 3. pp. 161-184. Academic Press, New York.

Kal M. \& HaWthorne J. N. (1969) Ann. N.Y. Acad. Sci. 165. $76 !-773$.

Kkough K. M. W. \& ThOMPSON W. (1972) Biochim biophys. Acta 270, 324-336.
Lowry O. H., Rosebrough N. J., FarR A. L. \& Randall R. J. (1951) J. biol. Chem. 193, 265-275.

Margolis R. U. \& Heller A. (1966) J. Pharmac. exp. Ther. 151, 307-312.

Molitor H. \& Kuna S. (1947) Archs int. Pharmacodyn. Ther. 74, 334-342.

Mora P. T., Young B. G. \& Shear M. J. (1959) Nature, Lond. 184, 431-432.

Pestka S. (1971) A. Rev. Biochem. 40, 697-710.

Pittinger C. \& Adamson R. (1972) A. Rev. Pharmac. 12, 169-184.

Pumphrey A. M. (1969) Biochem J. 112, 61-70.

Quick C. E., FisH A. \& BRown C. (1973) Laryngoscope 83, $1469-1482$.

Ravch S. \& KöstLin A. (1964) in Biochemie des Innenohres (RAuch S., ed.) pp. 211-241. G. Thieme Verlag, Stuttgart. Redman C. M. (1972) Biochim. biophys. Acta 282. 123-134.

Santiago-Calvo E., Mulé S., Redman C. M., Hokin M. R. \& HoKIN L. E. (1964) Biochim. biophys. Acta 84, $550-562$.

SCatChard G. (1949) Ann N.Y. Acad. Sci. 51, 660-672.

Schacht J. (1974a) Trans. Am. Soc. Neurochem. 5, 66.

ScHachT J. (1974b) Ann. Otol. Rhinol. Lar. 83, 613-618.

SCHAChT J. \& AGRanoff B. W. (1972) J. Neurochem. 19, 1417-1421.

SChacht J. \& AGRanofF B. W. (1974a) J. Neurochem. 22, 473-478.

Schacht J. \& AGranoff B. W. (1974b) J. hiol. Chem. 249, 1551-1557.

Sheltawy A. \& Dawson R. M. C. (1969) Biochem. J. 111, 157-165.

SkiPSki V. P., Peterson R. F. \& Barclay M. (1964) Biochem. J. 90, 374-378.

Stupp H. F. (1970) Acta Oto-laryng. Suppl. 262, 1-85.

Stavinoha W. B., Pepelco B. \& Smith P. W. (1970) Pharmacologist 12, 257.

Thalmann I., Matschinsky F. M. \& Thalmann R. (1970) Ann. Otol. Rhinol. Lar. 79, 12-29.

Thalmann R., Thalmann I. \& Comegys T. H. (1972) Laryngoscope 82, 2059-2078.

Tou J.-S., Hurst M. W., Baricos W. H. \& Huggins C. G. (1972) Archs Biochem. Biophys. 149, 146-152.

Vital Brazil O. \& Prado-Franceschi J. (1969) Archs int. Pharmacodyn. Ther. 179, 65-77.

WERSÄLl J. \& Flock A. (1964) Life Sci. 3, 1151-1155.

White G. L., Schellhase H. U. \& Hawthorne J. N. (1974) J. Neurochem. 22, 149-158. 